Doi: $10.15863 / \mathrm{TAS}$

\section{International Scientific Journal}

\section{Theoretical \& Applied Science}

p-ISSN: 2308-4944 (print) e-ISSN: 2409-0085 (online)

Year: $2015 \quad$ Issue: $01 \quad$ Volume: 21

Published: $30.01 .2015 \quad$ http://www.T-Science.org
Aktolkyn Koshkarbaevna Moldalieva

Postgraduate student in $\mathrm{PhD}$ programme

The faculty of social science, law department, International Kazakh-Turkish University by name of H.A.Yessevi, Kazakhstan

Kairat Tutlybaevich Bitemirov Candidate of law science (PhD), professor. The faculty of social Science, Law department, International Kazakh-Turkish University by name of H.A.Yessevi, Kazakhstan

SECTION 32. Jurisprudence.
Yernar Sailaubekovich Shalkharov

Postgraduate student in $\mathrm{PhD}$ programme

The faculty of social science, law department International Kazakh-Turkish University by name of H.A.Yessevi, Kazakhstan. yernar_shalkharov@bk.ru

\title{
VARIETY OF NECESSITY OF DIVIDING LEGAL CROSS-SECTIONS INTO SEGMENTED SPECIALTIES IN LAW EDUCATION SYSTEM
}

Abstract: In this paper there were presented present situation in law education system, its advantages and disadvantages with ways of goal achieving system from position of dividing principle of strategic research. Also, there were shown main ways and strategies of improving law education in Kazakhstan Republic.

Key words: education, transaction, action, dissection, argument, goal, standard, inhabit, contingent, population, variety, quantity, quality.

Language: English

Citation: Moldalieva AK, Bitemirov KT, Shalkharov YS (2015) VARIETY OF NECESSITY OF DIVIDING LEGAL CROSS-SECTIONS INTO SEGMENTED SPECIALTIES IN LAW EDUCATION SYSTEM. ISJ Theoretical \& Applied Science 01 (21): 121-125. doi: http://dx.doi.org/10.15863/TAS.2015.01.21.20

\section{Introduction.}

Nowadays one of the most actual issues in the state is a system of legal education, as those are lawyers who are the main driving force of economic, social and industrial progress in the society. This statement is true and confirms this fact by the very text of the Constitution of the Republic of Kazakhstan, where the Republic of Kazakhstan promotes itself as a rule-of-law state. Consequently, all the internal mechanisms are to be performed by recorded means, which falls within the competence of lawyers. However, in under the actual system of education a legal department graduate is to have mastered all the instruments of intrastate and external state mechanisms in full. It is practically impossible. Eventually the following problems arise:

- Corruption in higher educational institutions;

- Improper gaining of basic level information;

- Unemployment.

\section{Main Points}

Now as a primary objective of the research one is to allocate the differentiation of sector-specific cross-sections for the increase in the coefficient of efficiency of specialists on the legal services market
$[1$, p. 5]. In order to conduct this research there is a number of tasks to be performed, that could be formulated as the following items:

1. The development of the system of occupational guidance of undergraduates in view of a specific cross-section.

2. The formulation of the academic plan of study for undergraduates of the administrative cross-section.

3. The formulations of the academic plan of study for undergraduates of the law enforcement cross-section.

4. The formulation of the academic plan of study for undergraduates of the environment-oriented cross-section.

5. The formulation of the academic plan of study for undergraduates of the civil crosssection.

6. The formulation of the academic plan of study for undergraduates of the business cross-section.

7. The formulation of the academic plan of study for undergraduates of the industrial cross-section. 
8. The formulation of the academic plan of study for undergraduates of the procedural cross-section.

The performance of these tasks is of particular significance in the system of education of the Republic of Kazakhstan as due to the poor quality of education provided by the actual system of legal education it is necessary to implement the policy of differentiation of overall profile lawyers into the following cross-section legal specialists under certain specialties into the legal education system:

1. State purpose cross-sections.

2. Social purpose cross-sections.

3. Business purpose cross-sections.

This project could become of a great benefit to the program of training of lawyers, as this policy is a powerful instrument of modernization of legal consciousness of the society and prevention of legal nihilism in the state [2, p. 8]. Furthermore, it is characterized by several benefits closely related with the national course of "Kazakhstan'2050", where one of the main tasks of the state on the internal level is, first of all, the development of small and mediumsized businesses and, second, the improvement of the mechanism of action of the state machinery, and, third, the social well-being of citizens (see Table 1).

With regard to the first task of the "Development of small and medium-sized businesses", it is the competent line-up of legal profile employees required for the successful operations of any organization within the framework of the "Customs Union" and the "World Trade Organization", where local legal entities would prevail, as a rule, as in the territory of the Republic of Kazakhstan the business cross-section lawyers would be able to adequately perform whichever legal tasks on the national level unlike their foreign competitors for whom numerous legal instruments would be of novelty [3, p. 14]. Thus, in under enhanced study of solely the disciplines directly related with practice activities and dual system of education, a business cross-section lawyer shall be practically capable of easily manoeuvring in such fields, as entrepreneurship, public sector, financial sector, tax sector, corporate legal relations [4, p. 9]. This will enable the perspective formation of two models of operations of legal profile specialists serving national organizations irrespective of their legal organizational form $[5$, p. 11].

- First model: macro service. Following this model a large organization with the following distinctly specialized divisions operates on the legal services market: General Entrepreneurship Division, Budget Planning Division, Financial Issues Division, Tax Risks Division, Corporate Legal Relations Division, etc. the main resources of which are crosssection lawyers working in these divisions, where each employee would be assigned a specific number of legal entities provided customer support by the entire organization with regard to specific issues (see Chart 1).

- Second model: micro service. Following this model a certain state register of legal department graduates, who register online with a special organization, is formed. Legal entities will be able to provide tasks online, that the employees will perform within an electronic register and submit to customers by means of certificates of acceptance, according to works performed by the end of a certain term each lawyer would accumulate a certain number of points, based on which one's salary would be calculated (see Figure [6, p. 12].

1) Regarding the second task of improvement of the mechanism of action of the state machinery, lawyers who have acquired a higher education under a proposed cross-section, will be able to start orientating in the procedure of employment with public authorities faster, including the obtaining of government reserve with a professional examination, continuing with the interviewing procedure and ending with the state of the special verification by HR of the National Security Committee Department $[7$, p. 5]. Second, within the framework of competence they will master the hierarchy and legal interrelations of all the public authorities, which shall allow the more competent execution of reports to such public authorities as the Crime Statistics and Special Registration Committee Department (CSSRCD) of the Prosecutor General's Office of the RK. Among other matters they will be able to accumulate the period of work in advance due to the dual education that could be performed by means of a roadmap, as well as by means of an official employment at the position not requiring the availability of a higher education, for instance, a court bailiff [8, p. 23]. Thus, the graduates would have the following 3 benefits in public sector:

- Orientation in employment.

- Orientation in competences and interdepartmental legal relations.

- Accumulation of a period of work.

Regarding the third task, it is the industry that was always of a key significance in the development of a state [9, p. 15]. However, as a rule, the lawyers operating in the field of manufacture have no command of principal regulations governing nearly the entire manufacture, confining themselves only to the basics of the corporate legislation and employment and labour statutes, though often the employment of labour is to be put within the quota standards of engagement of foreign labour [10, p. 3].

Thus, it is quite obvious that the implementation of this system of legal education would allow making an enormous progress in the system of legal education of the Republic of Kazakhstan. 


\section{FIELDS OF COMPETENCE OF UNDERGRADUATES}

Table 1

\begin{tabular}{|c|c|c|c|c|c|}
\hline & $\begin{array}{c}\text { CROSS- } \\
\text { SECTION }\end{array}$ & $\begin{array}{c}\text { PLACE OF } \\
\text { EMPLOYMENT }\end{array}$ & SOURCES & OCCUPATION & $\begin{array}{l}\text { SPECIFI } \\
\text { CITY }\end{array}$ \\
\hline 1 & $\begin{array}{l}\text { Lawyer of } \\
\text { administrat } \\
\text { ive cross- } \\
\text { section }\end{array}$ & $\begin{array}{l}\text { Public authorities, local } \\
\text { self-government } \\
\text { authorities. Ministries. } \\
\text { Agencies. Departments. } \\
\text { Administrations. }\end{array}$ & $\begin{array}{l}\text { 1. Constitution of the RK. } \\
\text { 2. Code of Administrative } \\
\text { Offences of the RK. } \\
\text { 3. Administrative Code. } \\
\text { 4. Governmental Decrees. } \\
\text { 5. Orders of executive } \\
\text { authorities. } \\
\text { 6. Law of the RK "On State } \\
\text { Service". } \\
\text { 7. Law of the RK "On } \\
\text { Corruption". } \\
\text { 8. Other sources. }\end{array}$ & Operations & $\begin{array}{c}\text { Audit. } \\
\text { Communit } \\
\text { y affairs. }\end{array}$ \\
\hline 2 & $\begin{array}{l}\text { Lawyer of } \\
\text { law } \\
\text { enforceme } \\
\text { nt cross- } \\
\text { section }\end{array}$ & $\begin{array}{l}\text { Prosecutor's supervision } \\
\text { authorities. } \\
\text { Court administration } \\
\text { authorities. } \\
\text { Internal } \\
\text { authorities. } \\
\text { Investigative authorities. } \\
\text { Forensics laboratories. } \\
\text { Court Bailiffs Service. } \\
\text { Interpol Office in the } \\
\text { RK. } \\
\text { Law enforcement } \\
\text { officers. }\end{array}$ & $\begin{array}{l}\text { 1. Criminal Code of the RK. } \\
\text { 2. Criminal Procedural Code } \\
\text { of the RK. } \\
\text { 3. Correctional Code of the } \\
\text { RK. } \\
\text { 4. Prosecutor's supervision. } \\
\text { 5. Law of the RK "On } \\
\text { Operational } \\
\text { Investigations". } \\
\text { 6. Other sources. }\end{array}$ & Operations & $\begin{array}{c}\text { Audit. } \\
\text { Communit } \\
\text { y affairs. }\end{array}$ \\
\hline 3 & $\begin{array}{l}\text { Lawyer of } \\
\text { environme } \\
\text { nt-oriented } \\
\text { cross- } \\
\text { section }\end{array}$ & $\begin{array}{l}\text { Environment-oriented } \\
\text { Inspectorates. } \\
\text { Inspectorates. } \\
\text { Departments. } \\
\text { Administrations. } \\
\text { Agencies. } \\
\text { Environmental Services. }\end{array}$ & $\begin{array}{l}\text { 1. Forestry Code. } \\
\text { 2. Water Code. } \\
\text { 3. Law of the RK "On } \\
\text { Subsoil". } \\
\text { 4. Environmental Code. } \\
\text { 5. Land Code. } \\
\text { 6. Other sources. }\end{array}$ & Operations. & $\begin{array}{l}\text { Audit. } \\
\text { Field } \\
\text { work. }\end{array}$ \\
\hline 4 & $\begin{array}{l}\text { Lawyer of } \\
\text { civil cross- } \\
\text { section }\end{array}$ & $\begin{array}{l}\text { Bar Council. } \\
\text { Notary Chamber. } \\
\text { Entrepreneurial } \\
\text { Chamber. } \\
\text { Public Service Center. } \\
\text { Non-governmental } \\
\text { organizations. }\end{array}$ & $\begin{array}{l}\text { 1. Civil Code of the RK. } \\
\text { 2. Civil Procedural Code of } \\
\text { the RK. } \\
\text { 3. Family Code. } \\
\text { 4. Law of the RK "On } \\
\text { Protection of Consumer } \\
\text { Rights". } \\
\text { 5. Law of the RK "On } \\
\text { Healthcare System". } \\
\text { 6. Other sources. }\end{array}$ & Consulting & $\begin{array}{c}\text { Communit } \\
\text { y affairs }\end{array}$ \\
\hline 5 & $\begin{array}{l}\text { Lawyer of } \\
\text { business } \\
\text { cross- } \\
\text { section. }\end{array}$ & $\begin{array}{l}\text { Business legal entities. } \\
\text { Associations. } \\
\text { Funds. } \\
\text { Banks. } \\
\text { Auctions. } \\
\text { International companies. } \\
\text { Bankruptcy } \\
\text { commissioners. }\end{array}$ & & Consulting. & $\begin{array}{c}\text { Audit. } \\
\text { Communit } \\
\text { y affairs. } \\
\text { Business } \\
\text { trips. }\end{array}$ \\
\hline 6 & Lawyer of & Industrial facilities. & & Consulting. & Field \\
\hline
\end{tabular}




\begin{tabular}{|c|c|c|c|c|}
\hline & $\begin{array}{l}\text { Industrial } \\
\text { cross- } \\
\text { section. }\end{array}$ & $\begin{array}{l}\text { Workshops. } \\
\text { Industrial complexes. } \\
\text { Plants. } \\
\text { Construction companies. } \\
\text { Owner-operated farms. } \\
\text { Manufacturing } \\
\text { cooperatives. } \\
\text { Construction companies. } \\
\text { Land deposits. }\end{array}$ & & $\begin{array}{c}\text { work. } \\
\text { Operations } \\
\text { Audit. } \\
\text { Communit } \\
\text { y affairs. } \\
\text { Business } \\
\text { trips. }\end{array}$ \\
\hline 7 & $\begin{array}{l}\text { Lawyer of } \\
\text { procedural } \\
\text { cross- } \\
\text { section. }\end{array}$ & & Operations. & \\
\hline
\end{tabular}

\section{SWOT ANALYSES}

Table 2

\begin{tabular}{|l|l|}
\hline Strengths & Weaknesses \\
\hline 1. Strengthening of a graduate's theoretical knowledge. & 1 Tunnel vision of graduates. \\
2. Saving of time for mastering necessary professional skills. & \\
3. Motivation of students. & Threats \\
\hline Opportunities & 1 Lack of certain cross-section lawyers. \\
\hline $\begin{array}{l}\text { 1. Decrease in the level of unemployment among lawyers. } \\
\text { 2. Provision of the market with highly trained specialized staff. }\end{array}$
\end{tabular}

DIVISION OF CONTEMPORARY SECTIONS

Table 3

\begin{tabular}{|c|c|c|c|c|c|c|c|}
\hline \multirow[t]{2}{*}{ No } & \multicolumn{3}{|c|}{ STATE PURPOSE CROSS-SECTIONS } & $\begin{array}{l}\text { SOCIAL PURPOSE } \\
\text { CROSS-SECTIONS }\end{array}$ & \multicolumn{3}{|c|}{$\begin{array}{l}\text { BUSINESS PURPOSE CROSS- } \\
\text { SECTIONS }\end{array}$} \\
\hline & $\begin{array}{c}\text { Lawyer of } \\
\text { administrati } \\
\text { ve cross- } \\
\text { section }\end{array}$ & $\begin{array}{l}\text { Lawyer of law } \\
\text { enforcement } \\
\text { cross-section }\end{array}$ & $\begin{array}{c}\text { Lawyer of } \\
\text { environment- } \\
\text { oriented cross- } \\
\text { section }\end{array}$ & $\begin{array}{l}\text { Lawyer of civil cross- } \\
\text { section }\end{array}$ & $\begin{array}{c}\text { Lawyer of } \\
\text { business cross- } \\
\text { section }\end{array}$ & $\begin{array}{l}\text { Lawyer } \\
\text { of } \\
\text { industria } \\
\text { l cross- } \\
\text { section }\end{array}$ & $\begin{array}{l}\text { Lawyer of } \\
\text { procedural } \\
\text { cross- } \\
\text { section }\end{array}$ \\
\hline 1 & $\begin{array}{l}\text { Field of } \\
\text { administrative } \\
\text { law }\end{array}$ & Law of crime & $\begin{array}{l}\text { Field of aquatic } \\
\text { resources }\end{array}$ & $\begin{array}{l}\text { Field of protection of } \\
\text { consumer rights. }\end{array}$ & $\begin{array}{l}\text { Field of } \\
\text { entrepreneurshi } \\
\mathrm{p}\end{array}$ & $\begin{array}{l}\text { Field of } \\
\text { industry. }\end{array}$ & $\begin{array}{l}\text { Field of civil } \\
\text { proceedings }\end{array}$ \\
\hline 2 & $\begin{array}{l}\text { Field of } \\
\text { customs law }\end{array}$ & $\begin{array}{l}\text { Prosecutor's } \\
\text { supervision }\end{array}$ & Field of forestry & $\begin{array}{l}\text { Field of intellectual property } \\
\text { rights }\end{array}$ & $\begin{array}{l}\text { Field of budget } \\
\text { law }\end{array}$ & $\begin{array}{l}\text { Field of } \\
\text { constructi } \\
\text { on }\end{array}$ & $\begin{array}{l}\text { Field of } \\
\text { criminal } \\
\text { proceedings }\end{array}$ \\
\hline 3 & & $\begin{array}{l}\text { Operational } \\
\text { investigations }\end{array}$ & $\begin{array}{l}\text { Field of subsoil } \\
\text { management }\end{array}$ & Field of family law & $\begin{array}{l}\text { Field of } \\
\text { financial law }\end{array}$ & $\begin{array}{l}\text { Field of } \\
\text { land } \\
\text { matters }\end{array}$ & $\begin{array}{l}\text { Field of } \\
\text { divorce } \\
\text { proceedings }\end{array}$ \\
\hline 4 & & Forensics & Field of mining & Field of Notariat & Field of tax law & & \\
\hline 5 & & Criminology. & $\begin{array}{l}\text { Field of } \\
\text { environment }\end{array}$ & Field of healthcare & $\begin{array}{l}\text { Field of } \\
\text { employment } \\
\text { and labour law. }\end{array}$ & & \\
\hline
\end{tabular}

\section{Conclusion}

To achieve the said goals it is necessary to perform the training of competent research lawyers within the framework of Ph.D. program, who would be capable of analysing and critical thinking while in under a scientific approach. Thus, training of undergraduate level specialists requires the most post powerful staff resources. This reform would allow national higher educational institutions to train specialists operating more professionally on the internal and external legal services markets. 


\section{References:}

1. (2015) Evolvement and development of higher legal education in the USA. Available: http://www.dissercat.com/content/stanovlenie-irazvitie-vysshego-yuridicheskogoobrazovaniya-ssha (Accessed: 20.01.2015).

2. (2015) State legal provision of training of legal staff at the universities of Russian Empire. Available:

http://www.dissercat.com/content/gosudarstven no-pravovoe-obespechenie-podgotovkiyuridicheskikh-kadrov-v-universitetakh-rossi (Accessed: 20.01.2015).

3. (2015) Social and cultural status of economic and legal education in modernizing society. Available:

http://www.dissercat.com/content/sotsiokulturn yi-status-ekonomicheskogo-i-yuridicheskogoobrazovaniya-v-moderniziruyushchems-0 (Accessed: 20.01.2015).

4. (2015) Peculiarities of arrangement of the activities of an educational complex (legal class - institute) in the system of legal education of the Ministry of Internal Affairs of Russia. Available:

http://www.dissercat.com/content/osobennostiorganizatsii-deyatelnosti-uchebnovospitatelnogo-kompleksa-yuridicheskii-klass-i (Accessed: 20.01.2015).

5. (2015) Formation of pedagogical competence of students in the system of higher legal education.

Available:

http://www.dissercat.com/content/formirovaniepedagogicheskoi-kompetentnosti-u-studentovv-sisteme-vysshego-yuridicheskogo-ob

(Accessed: 20.01.2015).
6. (2015) Historical evolution, theory and experience of integration of pedagogical culture into legal education. Available: http://www.dissercat.com/content/istoricheskay a-evolyutsiya-teoriya-i-opyt-integratsiipedagogicheskoi-kultury-v-yuridichesko (Accessed: 20.01.2015).

7. (2015) Problems of reformation of legal education in Russian Federation: Issues of General Theory and Methodology. Available: http://www.dissercat.com/content/problemyreformirovaniya-yuridicheskogo-obrazovaniyav-rossiiskoi-federatsii-voprosy-obshche (Accessed: 20.01.2015).

8. (2015) Social and cultural status of economic and legal education in modernizing society. Available:

http://www.dissercat.com/content/sotsiokulturn yi-status-ekonomicheskogo-i-yuridicheskogoobrazovaniya-v-moderniziruyushchemsy (Accessed: 20.01.2015).

9. (2015) Legal socialization of an individual in the context of legal upbringing and legal education. Available: - http://www.dissercat.com/content/pravovayasotsializatsiya-lichnosti-v-kontekste-pravovogovospitaniya-i-yuridicheskogo-obraz (Accessed: 20.01.2015).

10. (2015) Legal education in post-reform Russia: mid-to-late XIX century - early XX century. Available:

http://www.dissercat.com/content/yuridichesko e-obrazovanie-v-poreformennoi-rossii-vtorayapolovina-xix-nachalo-XX-vV 20.01.2015). 